\title{
The presence of violence at work of health care personnel and their work ability
}

\author{
Santa Bula ${ }^{1,}$, Liana Deklava ${ }^{1}$, Jelena Reste $^{1}$, and Inese Lusena-Ezera ${ }^{2}$ \\ ${ }^{1}$ Rīga Stradinsš University, Latvia \\ ${ }^{2}$ Liepaja University, Latvia
}

\begin{abstract}
Proportion of health care workers of those who believe that the work in progress threatens their health and safety is higher than the average in other sectors. Workers in health care facilities are especially exposed to violence in the workplace [1]. The aim of the study was the evaluation of the presence of violence at work and determination of its effect on the working ability of health care sector workers. The study included the survey of 132 emergency department employees (doctors, physician assistants, nurses) from Kurzeme Region hospitals (Latvia). Questionnaire of violence in the workplace of the health care sector workers and the work ability index assessment questionnaire were used for the data collection. It was found that medical staff of health care establishments experience mostly verbal abuse (97\%), less from physical attacks (36\%), and intimidation/bullying $(30 \%)$. The study found that medical personnel are aware of the changes implemented in the workplace (29\%), there has been no change (33\%), while the impact of changes implemented by medical staff at the workplace has not been experienced (47\%). For personnel who have suffered from violence in the workplace, working capacity is generally lower than for the personnel that has not experienced violence in the workplace.
\end{abstract}

Key words: violence in the health care sector, medical staff, working ability.

\section{Introduction}

Violence and stress in the workplace are serious threats for the companies and institutions, as well as for the society in general. In the European Union, special attention is paid to the violations at workplace, to pursuit, intimidation and harassment thus the consequences of this - collapse of organization, disagreements among the staff, bad company image, absence from work or spending time at work, change of human resources, accidents at work, "burnout" and payment of compensations - are seen more and more frequently [2]. "The statistics shows that $28 \%$ of European Union population suffer from three important psychosocial risk factors in the contemporary work environment: mobbing and bossing, sexual abuse; conflict situations among workers of different ages; burn-out and chronic fatigue syndrome" [3]. According to the world statistics data, chronic violence or victimization in the work environment (torture and intimidation) constitutes ca $18 \%$ of problems related with the psychosomatic health in the work environment that is the ground for being absent from work for up to two weeks [2].

\footnotetext{
* Corresponding author: santabula@inbox.lv
} 
As per Ž. Roja, I. Roja and H. Kaļkis [2], most part of Latvian population do not have current information on negative stress and workplace violence, on health disorders caused by psychosocial work risks and the possibilities to assess the mentioned risks. In authors' opinion, there is also no information on any preventive measures to reduce/prevent psychological terror (mobbing, bossing, disagreements and discrimination among workers of different ages, etc.). European data reveal that the proportion of health care workers who believe that their work threatens their health and safety is higher than the average in all other sectors (Health-care staff health protection and labour safety) and the studies show that the workers in health care facilities are especially exposed to workplace violence [1]. Also Ž. Roja, I. Roja, H. Kalksis have noted in their book "Stress and violence at work" [2] that the National labour safety and health protection institute recognizes the violence in the workplace of health-care workers as a dangerous labour risk factor. The existence of physical violence, e.g., pushing, beating, kicking, shooting, etc., at workplace is recognized rather long ago. Cases of physical violence at work are registered also in Latvia [2].

In the world, violence is registered most frequently in the admission units. In the United Kingdom, it has been found out that $50 \%$ of attacks to the health-care workers happen in the admission departments. Similarly, the violence rate against the nurses working in the admission departments is high also in the USA, Australia and Ireland. The current violence rate against the nurses working in the admission departments per 100 patients has the trend to increase from 2.0 to 2.8. The fact that most part of cases of violence is not registered should also be considered [1].

Health care workers need work environment where they feel safe, their health is not endangered and they can successfully carry out their duties [4]. According to the information in the report "Healthcare - most dangerous place for workplace injuries" provided by the Public Citizen, healthcare is the most dangerous sector, since 653,000 nurses, nurses, health care workers and others have been injured, traumatized or ill [5]. If workers are not provided with favourable working conditions or too high requirements are set [6], then in the course of time, stress and emotional overload can be observed, which may have an impact on employees' ability. Thereby, the studies mostly have been focused on the impact of various socio-demographic and psychosocial risks [7, 8], workload [9] shift/night work [10], and the health status of personnel $[9,11,12]$ on the medical staff work abilities.

In Latvia, violence towards the children and women is emphasised in the studies, but there are no studies of violence towards the medical staff, so this study was started. The aim of the study was to assess the existence of violence and determine its effect on the performance of workers in the health-care sector. In this study, the authors have tested the hypothesis that the performance of health care workers reduces under the influence of suffered violence. The present article discusses the results of Latvian health care staff questionnaire about the existence of violence in their workplace and about the changes of performance.

\section{Material and methods}

To achieve the aim of the study, two internationally validated questionnaires were used:

1) the questionnaire developed by the World Health Organization, International Labour Organization, International Nurses Council and International Public Services Organization about the assessment of violence in the workplaces in the health care sector (Workplace Violence in the Health Sector - Country Case Studies Research Instruments, Geneva, 2003) that is translated in Latvian;

2) the work ability index assessment tool developed by the Labour Protection Institute of Finland (Tuomi K. et al. "Work Ability Index" (the part of the "Respect for the 
Aging” programme) Institute of Occupational Health, Helsinki, 1994) that is translated in Latvian.

In general, 175 questionnaires were distributed, but 132 were recognized as valid. Only the complete questionnaires that were filled in according to the requirements were validated. Staff (doctors, physician assistants, nurses) from nine admission departments, trauma stations and Kurzeme Region emergency service were selected randomized as the respondents. All participants were informed that the participation in the study was voluntary, their answers were confidential and anonymous and that the original data were destroyed after the analysis.

The data obtained in the questionnaire was entered in the database by means of MS Office Excel and SPSS software, and grouped according to the age, sex, profession, level of work ability and other parameters of the study participants. Methods (Chi-squared criterion, contingency methods; Mann-Whitney $\mathrm{U}$ test) conforming to the data division were used to analyse the statistical data.

\section{Results and discussion}

In general, the participants of the study are aged from 20 to 59, 22\% of respondents are doctors, $38 \%$ - physician assistants and $40 \%$ - nurses. The questioned medical staff is aged mainly from 40 to 59: in the age group 40-44 there are $18 \%$ of respondents, in the age group $45-49$ there are $19 \%$ of respondents, $11 \%$ of respondents are aged 50-54, and $12 \%$ of respondents are in the 55-59 age group. Mostly women (78\%) and married respondents $(55 \%)$ participated in the study. Majority of the questioned respondents work in the hospitals $(92 \%)$ and are ordinary workers (84\%) with more than 20 years of seniority in the health sector $(46 \%) .68 \%$ of medical workers spend more than $50 \%$ of their time in main job in the emergency service. The summarized study data show that $93 \%$ of respondents work full load; $85 \%$ of respondents work in shifts, but $76 \%$ of respondents have had to work night shifts (from 6 p.m. to 7 a.m.). Almost all respondents (98\%) have contacts with patients during their working hours and $87 \%$ of respondents have a direct contact with patients/clients every day, as well medical staff works mainly with adults (97\%) and elderly persons (83\%).

The results of the questionnaire about the workplace violence show that the medical staff has suffered from psychological violence at their workplace during the last 12 months: $97 \%$ of respondents have suffered from verbal abuse and $30 \%$ of respondents have admitted that they have been intimidated or terrorized at their workplaces. $36 \%$ have suffered from physical attack, but sexual and racist harassment at workplace has occurred the least (in author's opinions these are individual cases). Following the results obtained in the study, it is established that irrespective of the number of hospitals and emergency aid services involved in the study, violence in general is encountered in all medical facilities involved in the study. Although physical attack and psychological violence is more experienced by the medical staff - women, staff aged from 20-29, 40-44 and 50-54, and in the work environment where one to ten workers, nurses and physician assistants spend most of the work time together. Research results reveal that mostly medical staff, who work in emergency, face physical attack (22\%), verbal abuse (62\%) and intimidation/bullying. Moreover, also respondents who work in general health care have faced it $(26 \%)$. Various researches prove that presence of violence in emergency services is widespread [13, 14], moreover, the most part of the victims are nurses. Notwithstanding the above, within the research in Latvia no statistically significant differences between the staff who has/has not suffered from workplace violence and age, sex of medical staff, number of employees and belonging to a particular professional group (doctor, physician assistants, nurse) are established $(p>0.05)$ (Table 1). Moreover, the data testify that nurses and physician assistants are more a subject of violence at work place. There is evidence also in other research that nurses are the main violence victims [15]. 
Similarly, the study results showed that there is no statistically significant difference $(p>0.05)$ (Table 1), whether the medical staff works shifts or night shifts - physical attacks, verbal abuse and intimidation/terrorization at workplace has been experienced by medical staff at the workplace during the last 12 months irrespective of the hour of day.

In the framework of the study, it was found out that the medical staff experienced violence directly from their clients. At the same time, comparative analysis has proved that the staff who have undergone verbal abuse and have been intimidated/terrorized, received it from the client's next of kin, relatives, workmates and managers; in cases of physical attacks - the clients $(89 \%)$ and the relatives of a client (22\%). The opposite situation was discovered in a research in Iran [15], Pakistan [16, 17], and China [18], where the main aggressors have been declared to be the relatives of a client or persons accompanying the client. This situation can be explained if considering social-cultural differences in Iran and Pakistan. Nevertheless, the scientists of Iran and China have taken the issue at a higher level by pointing out the necessity for applying appropriate laws and developing educational programs, thus targeting levels of the country and hospital itself, which would enable effective strategy towards decreasing and preventing the level of violence at work place.

In the case of the study in Latvia, it is worth highlighting the fact that only $51 \%$ of medical staff who have been a subject to verbal abuse and $21 \%$ of medical staff who have undergone intimidation reported the cases to the superiors. Unfortunately, the research unveils also the fact that in cases of psychological abuse the staff have fully neglected it, moreover, pretended it never happened. From psychological point of view, it can be taken as professionalism of the medical staff - the ability to deal with insults, being intimidated/terrorized, where the situations are not taken personally but seen in the context of the client's health issues, emotional and the current situation. However, the question remains whether and how the situation will long-term influence 1) medical staff's ability to work, 2) a will to proceed in a particular work place, 3 ) burn out. Those aspects need not only regular monitoring, but also longitudinal studies. Accordingly, summarizing the reasons stated by the medical staff who have not reported or told about the accident at work, it was revealed that respondents who were intimidated (74\%), verbally abused (60\%) and suffered from physical attack (55\%), have admitted that reporting/telling about what happened at their workplace would have been useless. At the same time, the results show that $40 \%$ of physical attack victims, $45 \%$ of verbally abused and $32 \%$ of intimidated/terrorized respondents have noted that the incident was not so important to report it.

While analyzing the medical staff's opinion on policy development regarding violence in work place, preventive measures taken and the utility of them, it has been found that medical staff have not been informed whether there are policies regarding physical, psychological, sexual and race violence, and it has been acknowledged that such policies do not exist. A similar situation has also been observed in other research on violence in workplace in medical institutions revealing lack of training [16, 19, 20] absence of the protocol and procedures on incidents [19-21], absence of strategies aimed at elimination of violence in the medical institution [19], as well as effective solution of communication problems involving violence [21].

This study has also revealed the fact that no significant attention is given to the development of human resources (only $20 \%$ respondents have admitted that the issue has been targeted at their work places). Not much attention has also been paid to education of the staff in improving their communication skills, conflict management, and acquiring self-defence (only $11 \%$ noted that the last is present in the work place). As to preventive measures at work place, the following have been carried out - safety measures (noted by $63 \%$ of respondents), limited access of unauthorized persons (noted by $58 \%$ of respondents), improvement of surroundings (noted by $50 \%$ of respondents) and special equipment or 


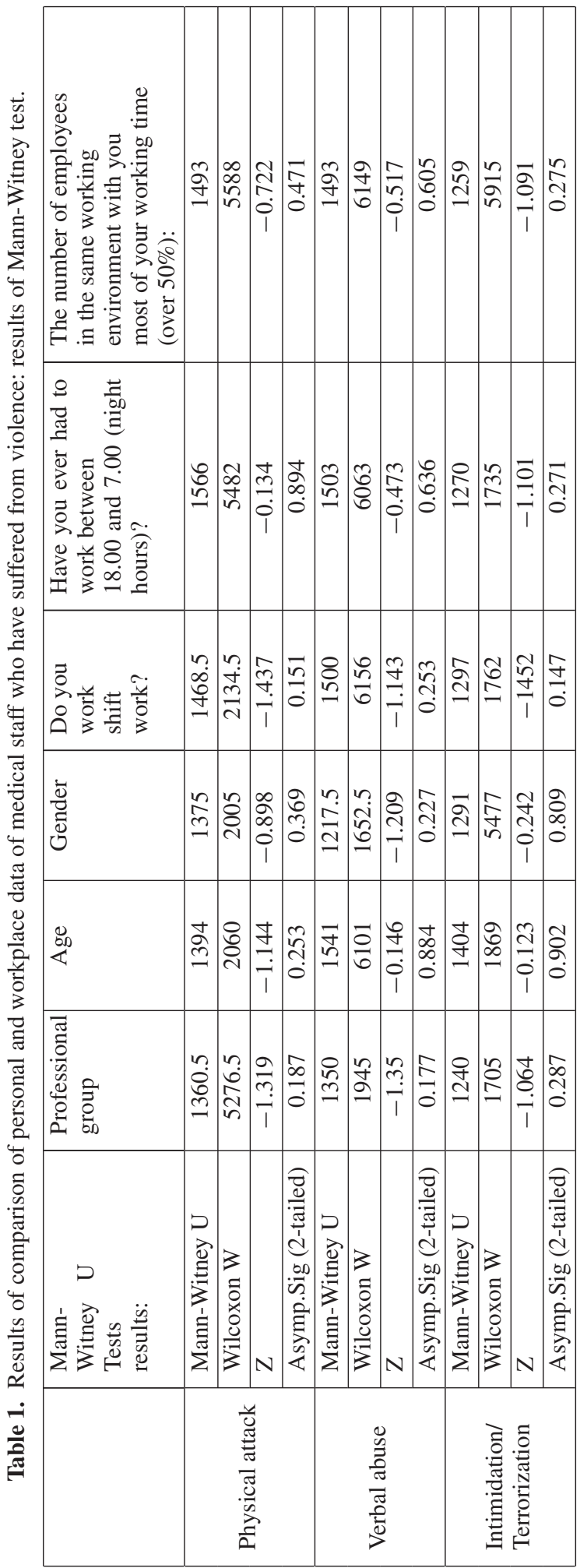


Table 2. Self-assessment of work abilities of medical staff depending on the experienced/ unexperienced workplace violence (\%).

\begin{tabular}{|c|c|c|c|c|c|c|c|}
\hline & & \multicolumn{2}{|c|}{ Physical attack } & \multicolumn{2}{|c|}{ Verbal abuse } & \multicolumn{2}{|c|}{$\begin{array}{l}\text { Intimidation/ } \\
\text { Terrorization }\end{array}$} \\
\hline & & yes & no & yes & no & yes & no \\
\hline \multirow{5}{*}{$\begin{array}{l}\text { How do you assess } \\
\text { your work abilities } \\
\text { when performing } \\
\text { physical work? }\end{array}$} & as very low & 0 & 0 & 0 & 0 & 0 & 0 \\
\hline & as low & 3 & 3 & 2 & 6 & 3 & 2 \\
\hline & as average & 25 & 21 & 26 & 12 & 30 & 21 \\
\hline & as good & 53 & 64 & 58 & 68 & 60 & 61 \\
\hline & as very good & 19 & 12 & 14 & 15 & 7 & 16 \\
\hline \multirow{5}{*}{$\begin{array}{l}\text { How do you assess } \\
\text { your work abilities } \\
\text { when performing } \\
\text { mental work? }\end{array}$} & as very low & 3 & 0 & 1 & 0 & 0 & 1 \\
\hline & as low & 6 & 1 & 2 & 3 & 7 & 1 \\
\hline & as average & 25 & 12 & 19 & 3 & 20 & 14 \\
\hline & as good & 44 & 73 & 61 & 74 & 63 & 64 \\
\hline & as very good & 22 & 14 & 17 & 21 & 10 & 20 \\
\hline
\end{tabular}

uniform (noted by $45 \%$ of respondents). Research indicates that the medical staff, especially nurses, lack knowledge of reacting in such situations, therefore being one of the most encouraging factors in physical violence cases among the client's and their relatives $[15,20]$. In addition, Croatia scientists have ascertained the lack of education whilst exploring working capability of medical staff (total 1856) in five hospitals in Zagreb. They noted that the staff lack knowledge of stress management and that there is imperfection in educating the staff regarding risks at work place. Despite the fact that the average work capacity index (WAI) for staff in Zagreb hospitals was very good, the researchers emphasized the necessity in preventive measures in order to maintain work capacity at organizational and individual levels [7]. Medical staff's ability to work is an issue of the management of a medical institution. It has been emphasized by other researchers, for example, in the research of work-related stress, education and work ability among hospital nurses in four university hospitals in Croatia [22]. It has been concluded that the duty of the hospital management is to solve the issues related to improving work conditions for nurses in the hospitals in Croatia. Moreover, an important role in maintaining nurses' ability to work is played by education and professional development. Similarly, in the research, carried out in Germany [23], the results acquired on doctors' ability to work, level of depression and occupational diseases make us come to the conclusion that the hospital management should plan and implement adequate strategies in promoting mental health. Moreover, efficiency of operations referring to optimisation of resource planning and improvement in the work process would also be the responsibility of hospital management [23].

Along with information gathered about the existence of violence, the work abilities of the medical staff working in Kurzeme Region health sector were also assessed by means of the work ability index (WAI). The assessment questionnaire has been developed by Institute of Occupational Health of Finland. Self-assessment of medical staff's work abilities, depending on whether the employee has/hasn't suffered from workplace violence revealed that the respondents have assessed their work abilities mainly with grade 8 (from 1 - very bad to 10 - very good). Such evaluation is given by $38.9 \%$ of physical attack victims and $40.7 \%$ of respondents who have not suffered from physical attack; $39.6 \%$ of respondents who have suffered from verbal abuse and $41.2 \%$ of respondents who have not experienced verbal abuse; $46.7 \%$ of respondents who have been intimidated/terrorized and $38.1 \%$ of respondents who have not experienced intimidation/terrorization. A different situation has been found related to the assessment of physical and mental abilities of the medical staff. The results in Table 2 
Table 3. Results of correlation between physical attacks and self-evaluation of medical staff's work abilities when carrying out mental work: results of Chi-squared test.

\begin{tabular}{|l|l|l|l|l|l|l|}
\hline & Value & df & $\begin{array}{l}\text { Asymp. } \\
\text { Sig. } \\
(2 \text {-sided) }\end{array}$ & $\begin{array}{l}\text { Exact } \\
\text { Sig. } \\
(2 \text {-sided })\end{array}$ & $\begin{array}{l}\text { Exact } \\
\text { Sig. } \\
(1 \text {-sided })\end{array}$ & $\begin{array}{l}\text { Point } \\
\text { Probability }\end{array}$ \\
\hline $\begin{array}{l}\text { Pearson } \\
\text { Chi-Square }\end{array}$ & $11.561^{\mathrm{a}}$ & 4 & .021 & .014 & & \\
\hline $\begin{array}{l}\text { Likelihood } \\
\text { ratio }\end{array}$ & 11.234 & 4 & .024 & .025 & & \\
\hline $\begin{array}{l}\text { Fisher's } \\
\text { exact test }\end{array}$ & 11.416 & & .106 & .121 & .072 & .031 \\
\hline $\begin{array}{l}\text { Linear-by- } \\
\text { linear } \\
\text { association }\end{array}$ & $2.610^{\mathrm{b}}$ & 1 & & & & \\
\hline $\begin{array}{l}\mathrm{N} \text { of Valid } \\
\text { Cases }\end{array}$ & 127 & \multicolumn{7}{|l|}{} & & & & \\
\hline \multicolumn{7}{|l|}{ a cells (40.0\%) have expected count less than 5. The minimum expected count is, 28. } \\
\hline
\end{tabular}

show that $73 \%$ of the respondents who during the last 12 months had not suffered from physical attacks in work places when carrying out mental work, have evaluated their work abilities as good. At the same time, only $44 \%$ of those who had suffered from physical attacks have assessed their work abilities as good.

Results of Chi-squared test reveal also statistically significant correlation between the experienced physical attack in work place and the assessment of medical staff's mental ability to work $(p<0.05)$ (Table 3). It can be explained with anxiety that has developed in case of suffered violence. As a result, disorders of psychological nature, e.g., difficulties to focus, are possible.

After having clarified medical staff's self-assessment of work abilities and mental abilities for the coming 2 years, it is to be concluded that the majority of respondents (70\%) are convinced of their abilities to perform the current work also in 2 years. The assessment of medical staff of how often they have gained satisfaction from their work, have been active and efficient, and optimistic about their future is less positive. Medical staff's answers to the question about absence from work (sick-leaves) were also clarified. The results showed that $57 \%$ of respondents who have not suffered from physical attack have not been absent from work due to sickness, but $42 \%$ of those who have suffered from physical attack have been absent from work for 10-24 days. Persons who suffered from physical attack have been mostly absent from work for 25 to 99 days (11\%) (Table 4).

Within the framework of the questionnaire, work ability index (WAI) was calculated for the workers in the health care sector. When comparing the WAI of medical staff depending on the experienced/inexperienced workplace violence, it can be concluded that bad, moderate and good WAI can be observed both for the staff who have suffered from physical attack and psychological violence and for the staff who have not experienced violence in their workplace. However, the results of WAI show also that moderate work abilities are encountered more frequently in staff who have suffered from verbal abuse (52\%), but good WAI is revealed more for the staff who have not experienced physical attack (13\%) and/or intimidation/terrorization (15\%) (Fig. 1).

Irrespective of the found WAI differences, a statistically significant relationship between the WAI and workplace violence was not established $(p>0.05)$ (Table 5). 
Table 4. Absence from work of medical staff depending on the experienced / inexperienced workplace violence (\%).

\begin{tabular}{|l|l|c|c|c|c|}
\hline \multicolumn{2}{|c|}{} & \multicolumn{4}{|c|}{$\begin{array}{l}\text { How many days have you been absent from work due to illness or } \\
\text { doctor's examination during the last 12 months? }\end{array}$} \\
\cline { 3 - 6 } \multicolumn{2}{|c|}{} & $\begin{array}{c}\text { totally } \\
25-99 \\
\text { days }\end{array}$ & $\begin{array}{c}\text { totally } \\
10-24 \\
\text { days }\end{array}$ & $\begin{array}{c}\text { totally to } \\
9 \text { days }\end{array}$ & $\begin{array}{c}\text { I haven't been absent } \\
\text { from work due to illness }\end{array}$ \\
\hline \multirow{2}{*}{ Physical attack } & yes & 11 & 42 & 22 & 25 \\
\cline { 2 - 6 } & no & 4 & 14 & 24 & 57 \\
\hline \multirow{2}{*}{$\begin{array}{l}\text { Verbal abuse } \\
\text { Intimidation/ }\end{array}$} & yes & 6 & 25 & 20 & 49 \\
\cline { 2 - 6 } & no & 6 & 15 & 32 & 47 \\
\cline { 2 - 6 } & yes & 7 & 27 & 13 & 53 \\
\hline
\end{tabular}

\section{Work ability index of medical staff:}

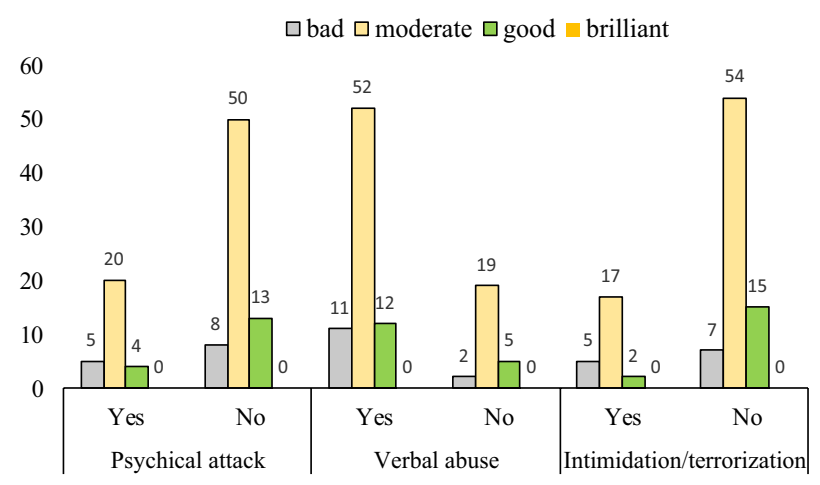

Fig. 1. Index of work ability of medical staff according to experienced/non-experienced violence in working place $\%$.

Table 5. Results of analysis of correlation between violence in workplace and work ability of medical staff.

\begin{tabular}{|l|l|c|}
\hline \multicolumn{2}{|c|}{} & Work Ability Index (WAI) \\
\hline \multirow{3}{*}{ Intimidation/terrorization } & Pearson Chi-Square & 3.450 \\
\cline { 2 - 3 } & $\mathrm{df}$ & 2 \\
\cline { 2 - 3 } & Asymp. Sig. (2-sided) & .178 \\
\hline \multirow{3}{*}{ Physical attack } & Pearson Chi-Square & 1.005 \\
\cline { 2 - 3 } & $\mathrm{df}$ & 2 \\
\cline { 2 - 3 } & Asymp. Sig. (2-sided) & .605 \\
\hline \multirow{3}{*}{ Verbal abuse } & Pearson Chi-Square & 1.959 \\
\cline { 2 - 3 } & df & 2 \\
\cline { 2 - 3 } & Asymp. Sig. (2-sided) & .375 \\
\hline
\end{tabular}

Assessment of work abilities of the health care staff testifies that, in general, the respondents assess their abilities as good in the present life span. Self-assessment of work abilities of medical staff depending on whether they have/have not suffered from violence in their workplace shows that workers who have suffered from physical attack, verbal abuse 
and intimidation/terrorization, have assessed their work abilities as bad, but the lowest self-assessment of work abilities of workers who have not suffered from workplace violence is average.

\section{Conclusions}

The study proves that violence occurs in completely all health care establishments involved in the study. Medical staff experience workplace violence irrespective of the age, sex and belonging to a professional group (doctors, physician assistants and nurses). The results showed that the staff, who have suffered from violence, have in general lower assessment of work abilities than the staff who have not experienced workplace violence. Apart from that, medical staff who have suffered from physical attack have more frequently been absent from work due to illness or doctor's visit. However, medical staff who have not experienced physical attack at work had higher assessment of work abilities in relation to mental load.

The study results show lack of good management in medical institutions that pays low or not enough attention to safe work place for the staff, and it shows the necessity to take preventive measures against violence in the workplaces of medical staff. The study results indicated, firstly, insufficient attention on the part of the management and the workers themselves to the training issues, such as conflict solving, self-defence, improvement of communication skills. It indicates a greater necessity for educating medical staff including completing the educational courses in order to avoid violence at work place, its elimination, dealing with it, recognition of aggressors, as well as providing psychological tactic in dealing with circumstances after such cases. Secondly, the study results indicate lack of reporting on the incidents, which leads to the conclusion that the employer tends to avoid resolving cases of violence. The study results noted that emergency service personnel experience the major part of violence (especially verbal insult) attacks, resulting in the need to pay more attention to establishing and providing security measures, such as considering permanent police or security post with operational call and report system, or at least providing the staff with mobile alert buttons.

Work ability level of medical staff having experienced violence at work place is lower than of those who have not. Although the research has not illustrated statistically significant connection between work ability level of medical staff and violence at work place, the influence on the medical staff's work ability level that carry out mental work and physical attack, and absence from work and physical attack have been noted.

\section{References}

[1] S. Touzet, P.L. Cornut, J.B. Fassier et al., BMC Health Services Res. 14, 221 (2014)

[2] Ž. Roja, I. Roja, H. Kalı̧is, Stress un vardarbība darbā. Ko darīt? SIA Media Pharma un Latvijas Ergonomikas biedrība: 94 (2016) (latv)

[3] V. Kalķ̧is, Ž. Roja, H. Kalķis, Arodveselība un riski darbāa. Medicīnas apgāds $\mathbf{5 3 3}$ (2015) (latv)

[4] Arodveselības un darba drošǐbas riski veselības aprūpes sektorā. Eiropas Komisija Nodarbinātības, sociālo lietu un iekļautības generāldirektorāts (Luksemburga: Eiropas Savienības Publikāciju birojs, 2013) (latv)

[5] C. Nordgvist, Healtcare most dangerous place for workplace injuries. Nursing/Midwifery. MNTSince (2013)

[6] K. Lapiņa, Psihosomātiskās sakarības un mūsdienu cilvēks. Rīga: 200 (2006) (latv.) 
[7] B. Knezević, R. Golubić, L. Belosević, M. et al., Acta Med. Croatia 64(5), 391-5 (2010)

[8] A.K. McGonagle, J.L. Barnes-Farrell, L. Di Milia et al., Eur. J. Work and Organ. Psychol. 23(6), 830-846 (2013)

[9] G. Costa, T.S. Sartori, B. Bertoldo et al., Int. Congr. Ser. 1280, 264-269 (2005)

[10] F.M. Fischer, F. Borges, L. Rotenberg et al., Chronobiology Int. 23(6), 1165-1179 (2009)

[11] S. van den Berg, A. Burdorf, S.J. Robroek, Int. Arch. Occup. Environ. Health 90(7), 685-693 (2017)

[12] M.A. da Silva, et al., Int. Arch. Med. 9(60), 1-8 (2016)

[13] J. Gacki-Smith, A.M. Juarez, L. Boyett et al., J. Nursing Adm. 39(7/8), 340-349 (2009)

[14] J. Crilly, W. Chaboyer, D. Creedy, Accident and Emergency Nursing 12(2), 67-73 (2004)

[15] M. Fallahi-Khoshknab, F. Oskouie, F. Najafi, N. Ghazanfari et.al., Iranian J. Nursing \& Midwifery Res. 21(3), 232-238 (2016)

[16] L. Ansari Baig et al., The J. Emergency Med. 1-9 (to be published, 2018)

[17] Z. Waleed, S. Emaduddin, E. Kiran et al., J. Emerg. Med. 45(5), 761-72 (2013)

[18] M. Jiao, N. Ning, Y. Li et al., BMJ Open 5, e006719 (2015)

[19] M. Pourshaikhian, G.H. Abolghasem, A. Aryankhesal et al., Arch. Trauma Res. 5(1), e28734 (2013)

[20] L.-Y. Lin, C.-W. Juan, C.-W. Juan, J. Acute Med. 4(1), 13-19 (2014)

[21] B. Heckemann, K.A. Peter, R.J.G. Halfens et al., J. Adv. Nursing 73(12), 3050-3060 (2017)

[22] R. Golubic, M. Milosevic, B. Knezevic, J. Mustajbegovic, J. Adv. Nursing 65, 2056-2066 (2009)

[23] M. Bernburg, K. Vitzthum, D.A. Groneberg et al., BMJ Open 6, e011369 (2016) 